\title{
FAKTOR-FAKTOR YANG MEMPENGARUHI PRODUKTIVITAS KARYAWAN (Studi Kasus pada CV Mitra Bersama Lestari Tahun 2014)
}

\author{
Budi Rismayadi \\ Universitas Buana Perjuangan Karawang \\ budi.rismayadi@ubpkarawang.ac.id
}

\begin{abstract}
ABSTRAK
Penelitian ini merupakan penelitian deskriptif yang bertujuan untuk mengetahui pengaruh baik secara parsial maupun simultan antara tingkat pendidikan, usia kerja , motivasi dan pengalaman kerja karyawan. Penelitian ini dilakukan pada CV Mitra Bersama Lestari dengan jumlah sebanyak 50 orang karyawan yang dijadikan sebagai sampel dalam penelitian ini. Sebelum dilakukan penelitian terlebih dahulu dilakukan uji Validitas dan releability, Uji Normalitas kemudian data diuji dengan menggunakan analisis regresi linier berganda . Beberapa hasil pengujian menunjukkan bahwa sebagian besar responden berdasarkan usia , motivasi, dan pengalaman kerja berpengaruh positif dan signifikan terhadap produktivitas kerja karyawan, sedangkan tingkat pendidikan tidak terbukti memiliki pengaruh signifikan terhadap produktivitas karyawan. Pengujian Secara simultan menunjukkan bahwa antara tingkat pendidikan, usia kerja, motivasi dan pengalaman kerja memiliki pengaruh yang signifikan terhadap produktivitas kerja karyawan .

Kata kunci : pendidikan, motivasi, usia kerja , pengalaman kerja , produktivitas
\end{abstract}

\section{PENDAHULUAN}

Sejarah perkembangan perekonomian Indonesia dewasa ini, memungkinkan dunia usaha akan mengalami pertumbuhan yang pesat dan akan dapat mendorong pembangunan ke arah yang lebih baik serta lebih memiliki kemampuan untuk dapat bersaing. Persaingan yang ketat telah menyebabkan banyak perusahaan yang mengalami kerugian dan bahkan terpaksa harus menutup perusahaan. Apalagi dengan adanya pasar bebas, persaingan dalam dunia usaha semakin terasa. Sehingga untuk dapat bersaing, perusahaan harus melakukan perbaikan-perbaikan dalam berbagai hal. Perbaikan yang utama adalah dibidang sumber daya manusia, karena sumber daya manusia merupakan faktor utama dalam kegiatan setiap operasional perusahaan.

Seiring dengan perkembangan dunia usaha yang semakin pesat tersebut, perusahaan-perusahaan akan terus menerus berusaha meningkatkan kualitas tenaga kerjanya dalam upaya menggerakkan perusahaan mereka, Mengingat 
dengan meningkatkan pembangunan sumber daya manusia atau tenaga kerja dianggap mampu meningkatkan mutu dan kemampuan usaha sesuai dengan kebutuhan dan harapan dunia usaha dengan tujuan mencapai output produktivitas yang tinggi.

Produktivitas tenaga kerja merupakan faktor yang sangat penting, karena produktivitas tenaga kerja memiliki peran besar dalam menentukan sukses tidaknya suatu perusahaan dalam mencapai tujuannya. Oleh karena itu produktivitas harus menjadi bagian yang tidak boleh dilupakan dalam menyusun strategi bisnis, yang mencakup bidang produksi, pemasaran, keuangan dan bidang-bidang lainnya.. Dengan meningkatkan produktivitas tenaga kerja ini secara tidak langsung akan berdampak pada peningkatan kepuasan kerja dari para pekerja, selain itu juga akan mendorong motivasi para pekerja untuk meningkatkan kinerja menjadi lebih baik lagi.

Permasalahan yang tidak kalah penting dalam manajemen sumber daya manusia adalah bagaimana mengetahui faktor-faktor yang mempengaruhi produktivitas kerja karyawannya. Factor yang mempengaruhi produktivitas kerja karyawan menjadi masalah yang rumit dan cukup penting untuk diteliti dikarenakan besarnya manfaat yang didapat dari meningkatnya produktivitas tenaga kerja karyawan sangat dipengaruhi oleh seberapa besar pengaruh factor factor lainnya, dan tentu saja pengaruh factor tersebut bagi individu, industri, dan masyarakat akan cukup besar pengaruhnya. Bagi individu, factor factor yang mempengarui produktivitas kerja karyawan memungkinkan mereka untuk lebih berusaha meningkatkan kebahagiaan hidup mereka. Sedangkan bagi industri, factor factor yang mempengaruhi produktivitas kerja karyawan digunakan sebagai indicator pemacu peningkatan produksi dan upaya efisiensi biaya perusahaan dengan mengoptimalkan peran tenaga kerja dalam membangun etos kerja yang tinggi dan menekankan pada perubahan perilaku tenaga kerja yang lebih baik.

Setiap organisasi pada dasarnya akan menerapkan kebijakan yang berbeda-beda terhadap sumber daya manusia yang dimilikinya guna mencapai produktivitas kerja karyawan. Dalam pencapaian produktivitas kerja karyawan terdapat banyak faktor yang mempengaruhinya, tetapi dalam hal ini factor factor yang diamati dan diduga memiliki pengaruh terhadap produktivitas tenaga kerja 
antara lain adalah tingkat pendidikan, motivasi, usia dan pengalaman kerja karyawan. Factor factor yang mempengaruhi produktivitas kerja karyawan tersebut diharapkan mampu memberikan jalan bagi karyawan guna mencapai produktivitas kerja yang sangat baik.

Permasalah produktivitas ini juga dialami dan muncul pada CV Mitra Bersama Lestari yang usahanya bergerak dibidang Supplier peralatan kantor, perusahan berupaya keras dalam upaya memenangkan persaingan pasar dengan lebih meningkatkan kualitas pelayanan kepada pelanggan dan melakukan perubahan dan pola manajemen yang baik agar lebih fleksibel dalam menghadapi persaingan. Upaya tersebut diatas diwujudkan dalam tujuan perusahaan yaitu untuk meningkatkan pendapatan hasil usaha yang ditempuh dengan cara mengoptimalkan produktivitas kerja karyawan. Pentingnya pencapaian produktivitas kerja ini dikarenakan produktivitas kerja pada dasarnya merupakan suatu sikap dengan cara pandang yang lebih baik bahwa mutu kehidupan hari ini harus lebih baik dari hari kemarin.

Dalam uraian di atas terlihat bahwa tujuan dari studi ini adalah untuk mengetahui dan menganalisis faktor-faktor yang mempengaruhi produktivitas kerja karyawan pada CV Mitra Bersama Lestari Selain itu juga perlu diketahui faktor yang paling dominan mempengaruhi produktivitas kerja karyawan.

\section{REVIEW LITERATUR DAN HIPOTESIS}

\section{Produktivitas Kerja}

Dalam kegiatannya setiap perusahaan akan selalu berusaha meningkatkan prestasi kerja karyawannya untuk mencapai produktivitas kerja yang maksimal. Produktivitas kerja bagi suatu perusahaan sangatlah penting sebagai alat pengukur keberhasilan dalam menjalankan usaha, semakin tinggi produktivitas kerja karyawan dalam perusahaan, akan mampu meningkatkan laba perusahaan.

Tjutju Yuniarsih \& Suwanto (2009:156) mengemukakan bahwa produktivitas kerja diartikan sebagai hasil kongkrit (produk) yang dihasilkan oleh individu atau kelompok, selama satuan waktu tertentu dalam suatu proses kerja. Dalam hal ini, bagaimana tenaga kerja mampu menyelesaikan pekerjaan dengan menghasilkan output dalam waktu yang relative lebih singkat, dengan kata lain 
produktivitas akan dapat dicapai manakala proses produksi membutuhkan waktu yang lebih pendek. Nawawi dalam Tjutju Yuniarsih (2009:157) mengemukakan bahwa produktivitas kerja merupakan perbandingan antara hasil yang diperoleh (output) dengan jumlah sumber daya yang dipergunakan sebagai masukan (input). Adapun Nanang Fattah dalam Tjuju Yuniarsih (2009:157) menyimpulkan bahwa dalam konsep produktivitas ber-kembang dari pengertian teknis sampai kepada pengertian prilaku. Produktivitas dalam penggertian teknis mengacu pada derajat keefektifan dan efisiensi dalam penggunaan berbagai sumber daya, sedangkan dalam pengertian prilaku, produktivitas merupakan sikap mental yang senantiasa berusaha untuk terus berkembang.

Berdasarkan uraian tersebut dapat dipahami produktivitas dapat dimaknai sebagai nilai output dalam interaksi dengan kesatuan nilai-nilai input. Produktivitas kerja karyawan biasanya dinyatakan sebagai imbangan hasil ratarata yang dicapai oleh tenaga kerja, selama jam kerja yang tersedia dalam proses produksi. Sehubungan dengan hal tersebut, konsep produktivitas pada dasarnya mencakup sikap mental dan prilaku yang berorientasi pada perbaikan berkelanjutan (continuous improvement), dan mempunyai pandangan bahwa kinerja hari ini harus lebih baik dari hari kemarin, dan kinerja hari esok mesti lebih baik dari prestasi hari ini.

Konsep produktivitas pada dasarnya dapat dilihat dari dua dimensi, yaitu dimensi individu dan dimensi organisasi. Pengkajian masalah produktivitas dari dimensi individu tidak lain melihat produktivitas terutama dalam hubungannya karakteristik-karakteristik kepribadian individu. Dalam konteks ini esensi pengertian produktivitas adalah sikap mental yang selalu mempunyai pandangan bahwa mutu kehidupan hari ini harus lebih baik dari hari kemarin, dan hari esok harus lebih baik dari hari ini (Kusnendi, 2003:8.4).

Dalam upaya meningkatkan produktivitas kerja karyawan di suatu perusahaan perlu memperhatikan faktor-faktor yang mempengaruhi produktivitas kerja karyawan tersebut. Banyak faktor yang mempengaruhi produktivitas kerja karyawan baik yang berhubungan dengan tenaga kerja itu sendiri maupun faktorfaktor yang berhubungan dengan lingkungan perusahaan dan kebijakan pemerintah secara keseluruhan. 
Menurut Pandji Anoraga (2005: 56-60). Ada 10 faktor yang sangat diinginkan oleh para karyawan untuk meningkatkan produktivitas kerja karyawan, yaitu: (1) pekerjaan yang menarik, (2) upah yang baik, (3) Keamanan dan perlindungan dalam pekerjaan, (4) etos kerja dan (5) lingkungan atau sarana kerja yang baik, (6) promosi dan perkembangan diri mereka sejalan dengan perkembangan perusahaan, (7) merasa terlibat dalam kegiatan-kegiatan organisai, (8) pengertian dan simpati atas persoalan-persoalan pribadi, (9) kesetian pimpinan pada diri sipekerja, (10) Disiplin kerja yang keras.

Menurut Payaman J. Simanjuntak (2007:30) faktor yang mempengaruhi produktivitas kerja karyawan perusahaan dapat digolongkan pada dua kelompok, yaitu: pertama, yang menyangkut kualitas dan kemampuan fisik karyawan yang meliputi: tingkat pendidikan, latihan, motivasi kerja, etos kerja, mental dan kemampuan fisik karyawan. Kedua, berupa sarana pendukung yang meliputi: a). Lingkungan kerja (Produksi, sarana dan peralatan produksi, tingkat keselamatan kerja). b) kesejahteraan karyawan (Manajemen dan hubungan industry).

Dari berbagai pendapat diatas dapat disimpulkan kondisi utama karyawan yang sangat penting dan menentukan tingkat produktivitas karyawan yaitu pendidikan dan pelatihan, motivasi, usia, disiplin, keterampilan, tingkat penghasilan, lingkungan dan pengalaman kerja, serta penguasaan peralatan. Dengan harapan agar karyawan semakin gairah dan mempunyai semangat dalam bekerja dan akhirnya dapat mempertinggi mutu pekerjaan, meningkatkn produksi dan produktivitas kerja.

Namun demikian penelitian ini hanya membatasi empat faktor yang diduga dapat mempengaruhi produktivitas kerja karyawan, yaitu tingkat pendidikan, motivasi,usia, dan pengalaman kerja. adapun alur kerangka pikirnya dapat digambar sebagai berikut:

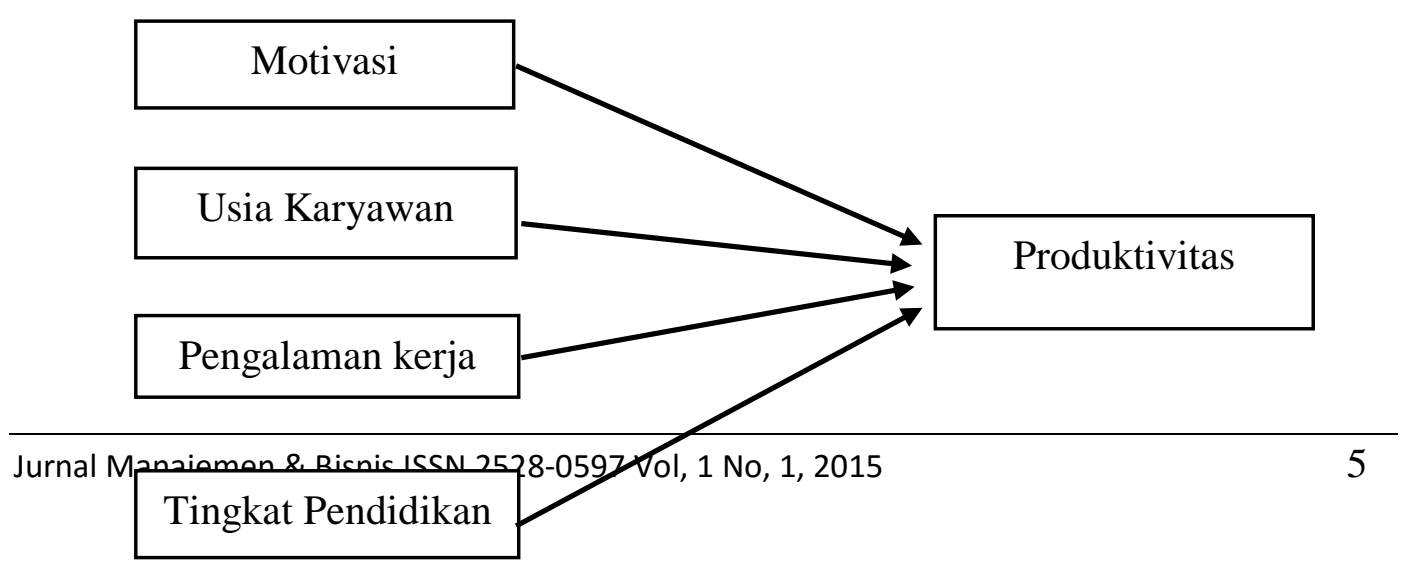




\section{Gambar 1 Kerangka Pikir Penelitian}

\section{Tingkat Pendidikan dan Produktivitas}

Bekal tingkat pendidikan yang cukup dan memadai diharapkan akan dapat memperbesar produktivitas kerja karyawan. Prestasi akademis yang telah dicapai semasa menempuh pendidikan sekolah menjadi salah satu pertimbangan. Dengan mempertimbangkan faktor prestasi akademis, maka dapat ditetapkan dimana karyawan yang bersangkutan akan ditempatkan sesuai dengan prestasi akademisnya.

Dengan melihat potensi sumber daya alam yang ada dan dapat dimanfaatkan oleh setiap masyarakat akan diperoleh data bagaimana usaha usaha yang dilakukan oleh masyarakat dalam upaya memenuhi pendapatannya, rendahnya kualitas sumber daya manusia dari segi pengetahuan dan keterampilan yang diduga disebabkan oleh rendahnya kualitas pendidikan dan pelatihan yang mereka peroleh sehingga menyebabkan pendapatan mereka pun sangat rendah. Sehingga dari hal tersebut dapat disusun hipotesis sebagai berikut:

$H_{1}$ : Diduga terdapat pengaruh positif dan signifikan tingkat pendidikan terhadap produktivitas karyawan.

\section{Motivasi Dan Produktivitas}

Menurut T. Hani Handoko (2003:252), motivasi adalah keadaan dalam pribadi seseorang yang mendorong keinginan individu untuk melakukan kegiatan kegiatan tertentu guna mencapai tujuan. Apabila seseorang sudah terdorong atau termotivasi, maka pekerjaan yang dilakukan hasilnya akan memuaskan. Memotivasi merupakan kegiatan yang mengakibatkan, menyalurkan dan memelihara prilaku manusia atau bisa dikatakan sebagai suatu proses untuk mencoba mempengaruhi seseorang agar melakukan sesuatu yang kita inginkan atau dengan kata lain dorongan dari luar terhadap seseorang agar mau melaksanakan sesuatu. 
Motivasi dalam diri karyawan sangat diperlukan untuk dapat meningkatkan produktivitas karyawan itu sendiri. Dengan adanya motivasi, seorang karyawan akan terdorong untuk melakukan kerja yang lebih baik daripada sebelumnya, dan hal ini akan meningkatkan produktivitas mereka. Maka dapat terlihat adanya suatu pengaruh antara motivasi karyawan terhadap produktivitasnya. Selanjutnya hubungan antara motivasi dan produktivitas dapat di hipotesiskan sebagai berikut:

$H_{2}$ : Diduga terdapat pengaruh positif dan signifikan motivasi terhadap produktivitas karyawan.

\section{Usia Karyawan Dan Produktivitas}

Dalam rangka menempatkan karyawan, faktor usia pada diri karyawan yang lulus dalam seleksi perlu mendapatkan pertimbangan. Hal tersebut bermaksud untuk menghindari rendahnya produktivitas yang dihasilkan oleh karyawan yang bersangkutan. Karyawan berusia lanjut berumur 65 tahun keatas, biasanya fanatik terhadap tradisi dan sulit untuk diberikan pengertian yang dapat merubah cara berpikir, cara kerja, dan cara hidupnya. Karyawan lanjut usia bersikap apatis terhadapa adanya teknologi baru. Usia tenaga kerja yang produktif berumur 16-64 tahun, sedangkan pada usia 65 keatas sudah dikatakan usisa lanjut (Van den Ban dan Hakwiks,1999). Oleh karena itu disusunlah hipotesis sebagai berikut:

$H_{3}$ : Diduga terdapat pengaruh positif dan signifikan usia karyawan terhadap produktivitas jaryawan.

\section{Pengalaman Kerja Dan Produktivitas}

Pengalaman dalam semua kegiatan sangat diperlukan, karena experience is the best teacher, Pengalaman guru terbaik. Maksud dari hal tersebut adalah bahwa seseorang belajar dari pengalaman yang sudah dialaminya. Menurut Kamus Bahasa Indonesia (Depdikans, 2005: 26), “ Pengalaman dapat diartikan sebagai yang pernah dialami (dijalani, dirasa, ditanggung, dsb) ".

Elaine B Johnson (2007:228) Menyatakan bahwa "Pengalaman memunculkan potensi seseorang”. Potensi penuh akan muncul bertahap seiring 
dengan berjalannya waktu sebagai tanggapan terhadap bermacam-macam pengalaman". Jadi sesungguhnya yang penting diperhatikan dalam hubungan tersebut adalah kemampuan seseorang untuk belajar dari pengalamannya, baik pengalaman manis maupun pahit. Maka pada hakikatnya pengalaman adalah pemahaman terhadap sesuatu yang dihayati dan dengan dihayati dan dengan penghayatan serta mengalami sesuatu tersebut diperoleh pengalaman, keterampilan ataupun nilai yang menyatu pada potensi diri. Orang yang berpengalaman dalam bekerja memiliki kemampuan kerja yang lebih baik daripada orang yang baru saja memasuki dunia kerja, karena orang tersebut telah belajar dari kegiatan-kegiatan dan permasalahan yang timbul dalam kerjanya. Dengan adanya pengalaman kerja maka telah terjadi proses penambahan ilmu pengetahuan dan keterampilan serta sikap pada diri seseorang, sehingga dapat menunjang dalam mengembangkan diri dengan perubahan yang ada, dengan pengalaman yang didapat seseorang akan lebih cakap dan terampil serta mampu melaksanakan tugas pekerjaannya.

Pengalaman kerja mempunyai pengaruh terhadap banyaknya produksi, besar kecilnya dan efisiensi yang dapat dilihat dari hasil produksi tenaga kerja yang diarahkan. Dalam pengertian lain, pengalaman kerja juga dapat diperoleh dengan melewati masa kerja yang telah dilalui disuatu tempat kerja. pengalaman kerja seseorang dalam suatu pekerjaan yang dimanifestasikan dalam jumlah masa kerja akan meningkatkan kemampuan dan kecakapan kerja seseorang sehingga hasil kerja akan semakin meningkat. Pengalaman kerja tidak hanya menyangkut jumlah masa kerja, tetapi lebih memperhitungkan jenis pekerjaan yang pernah atau sering dihadapi. Sejalan dengan bertambahnya pekerjaan, maka akan semakin bertambahnya pula pengetahuan dan keterampilan seseorang dalam bekerja. Hal tersebut dapat dipahami karena terlatih dan sering mengulang suatu pekerjaan sehingga kecakapan dan keterampilan semakin dikuasai secara mudah, tetapi sebelumnya tanpa latihan, pengalaman-pengalaman yang pernah dimiliki akan menjadi berkurang bahkan terlupakan.

Atas dasar uraian diatas, maka hipotesis yang bisa disusun adalah sebagai berikut: 
$H_{4}$ : Diduga terdapat pengaruh positif dan signifikan pengalam kerja terhadap produktivitas karyawan.

\section{METODE PENELITIAN}

Studi ini merupakan penelitian deskriptif dimana populasinya adalah seluruh karyawan ............yang berjumlah 50 orang. Mengingat populasi kurang dari 100, maka semua karyawan diambil sebagai sempel, sehingga penelitiannya merupakan penelitian populasi/sensus.

\section{Pengukuran Dan Definisi Operasional Variabel}

Variabel dependen dalam penelitian ini adalah produktivitas, yaitu ukuran tingkat pengguna sumber-sumber untuk mencapai sesuatu yang berhubungan dengan efektivitas dalam mencapai suatu misi atau prestasi yang diharapkan. Pengukuran variabel produktivitas karyawan menggunakan instrumen terdiri atas 3 pernyataan, disusun menggunakan skala likert 5 point (sangat tidak setuju sampai dengan sangat setuju).

Variabel independen dalam penelitan ini sebanyak 4 variabel yaitu:

a. Tingkat pendidikan, yaitu persepsi individu terhadap pekerjaan atas dasar pendidikan tertinggi.

b. Motivasi, yaitu persepsi individu terhadap keadaan dalam pribadi seseorang yang mendorong keinginan individu untuk melakukan kegiatankegiatan tertentu guna mencapai tujuan.

c. Usia, yaitu persepsi individu terhadap pekerjaan berdasar usia.

d. Pengalaman kerja, yaitu persepsi individu terhadap tingkat penguasaan pengetahuan serta keterampilan seseorang dalam pekerjaannya yang dapat diukur dari masa kerja dan dari tingkat pengetahuan serta keterampilan yang dimilikinya.

\section{Metode Analisis Data}

Metode analisis data dan Reliabilitas juga digunakan untuk menguji kuesioner yang akan diisi oleh responden. Hasil menunjukan bahwa semua item 
pernyataan yang ada dalam kuesioner sebanyak 19 item dinyatakan valid, keempat variable dinyatakan reliable.

Berdasarkan hasil perhitungan analisis Faktor terhadap ke lima variabel (produktivitas, tingkat pendidikan, motivasi, usia, dan pengalaman kerja) diperoleh hasil sebagai berikut: rata-rata indikator produktivitas karyawan, tingkat pendidikan, motivasi kerja, usia dan pengalaman kerja tidak menunjukan penyimpangan data hal tersebut dikarenakan nilai rata-rata lebih besar dari standar devisiasi.

Tabel 1 Statsitika Deskriptif

\begin{tabular}{|l|c|c|c|c|c|}
\hline & $\mathrm{N}$ & Minimum & Maximum & Mean & Std. Deviation \\
\hline $\begin{array}{l}\text { Produktivitas } \\
\text { karyawan }\end{array}$ & 50 & 2.50 & 3.75 & 2.9100 & 24620 \\
\hline $\begin{array}{l}\text { Tingkat } \\
\text { Pendidikan }\end{array}$ & 50 & 3.00 & 4.75 & 3.9150 & 33334 \\
\hline Motivasi kerja & 50 & 3.00 & 4.75 & 3.9100 & 34251 \\
\hline Usia & 50 & 3.00 & 4.50 & 3.8300 & 35871 \\
\hline Pengalaman Kerja & 50 & 3.00 & 4.75 & 3.8750 & 39528 \\
\hline Valid N (listwise) & 50 & & & & \\
\hline
\end{tabular}

Sumber: Data olah SPSS 16.00

Berdasarkan hasil Uji Asumsi Klasik diperoleh untuk uji Normalitas data yang digunakan dalam penelitian ini berdistribusi secara normal. Berdasar Uji Multikolinearitas model regresi tersebut tidak terdapat masalah multikolinearitas. Setelah dilakukan pengujian menggunakan Rank Spearman didapatkan bahwa variabel independen tidak mempunyai korelasi dengan residualnya. Dengan tingkat signifikansi masing-masing variabelnya lebih dari 5\%, sehingga dapat diambil kesimpulan bahwa tidak terdapat heteroskedastisitas.

\section{HASIL PENELITIAN DAN PEMBAHASAN}

Berdasarkan hasil perhitungan Analisis Regresi Linear Berganda diperoleh hasil sebagai berikut:

Tabel 2 Hasil Uji Regresi Linear Berganda

\begin{tabular}{|c|c|c|c|c|}
\hline Model & $\begin{array}{c}\text { Unstandardized } \\
\text { Coefficients }\end{array}$ & $\begin{array}{c}\text { Standardized } \\
\text { Coefficients }\end{array}$ & $\mathrm{t}$ & Sig \\
\hline
\end{tabular}




\begin{tabular}{|c|c|c|c|c|c|c|}
\hline \multicolumn{2}{|c|}{} & B & Std. Error & Beta & & \\
\hline \multirow{4}{*}{1} & (Constant) & 2.927 & 0.475 & & 6.612 & 0.000 \\
\cline { 2 - 7 } & $\begin{array}{c}\text { Tingkat } \\
\text { Pendididkan }\end{array}$ & 0.086 & 0.096 & 0.151 & 0.895 & 0.375 \\
\cline { 2 - 7 } Motivasi Kerja & -0.122 & 0.084 & 0.320 & 1.851 & 0.043 \\
\cline { 2 - 7 } & Pengalaman Kerja & -0.190 & 0.092 & 0.305 & 2.062 & 0.040 \\
\hline & Usia & -0.159 & 0.127 & 0.332 & 1.757 & 0.047 \\
\hline
\end{tabular}

a. Dependen Variabel: Produktivitas Karyawan

Sumber: Data olah SPSS 16.00

Pada tabel 2 diatas terlihat nilai t hitung untuk variabel tingkat pendidikan adalah 0.895 , sedangkan nilai t tabelnya adalah sebesar $1.750(\mathrm{df}=50-4-1=45)$. Selain itu, nilai signifikansinya didapat 0.375 . Sehingga didapat bahwa variabel tingkat pendidikan tidak berpengaruh terhadap produktivitas karyawan. Hal ini disebabkan niali $\mathrm{T}$ hitung lebih kecil daripada $\mathrm{t}$ tabel. Nilai $\mathrm{t}$ hitung $<\mathrm{t}$ tabel $(0.895<1,750)$ dan nilai signifikansi lebih besar daripada taraf signifikansi $(\alpha)$ $0,05(0,375>0,05)$, artinya tingkat pendidikan tidak berpengaruh positif dan signifikan terhadap produktivitas karyawan (Hipotesis 1 tidak terbukti).

Nilai t hitung untuk variabel motivasi kerja adalah 1.851, sedangkan nilai $\mathrm{t}$ tabelnya adalah sebesar $1.750(\mathrm{df}=50-4-1=45)$. Selain itu niali signifikansinya didapat 0,043. Sehingga didapat bahwa variabel motivasi kerja berpengaruh terhadap produktivitas karyawan. Hal ini disebbkan nilai $\mathrm{T}$ hitung lebih besar daripada t tabel. Nilai thitung > t tabel (1.851> taraf signifikansi $(\alpha) 0,05(0.043$ $<0,05)$, artinya motivasi kerja berpengaruh positif dan signifikan terhadap produktivitas karyawan (Hipotesis 2 terbukti).

Hipotesis 3 bisa dijawab dengan melihat $\mathrm{t}$ hitung untuk variabel Pengalaman kerja adalah 2.062, sedangkan nilai t tabelnya adalah sebesar 1.750 $(\mathrm{df}=50-4-1=45)$. Selain itu, nilai signifikansinya didapat 0,040. Sehingga didapat bahwa variabel pengalaman kerja berpengaruh terhadap produktivitas karyawan. Hal ini disebabkan nilai $\mathrm{T}$ hitung lebih besar daripada $\mathrm{t}$ tabel. Nilai $\mathrm{t}$ hitung > t tabel $(2.062>1,750)$ dan nilai signifikansi $(\alpha) 0,05(0,040<0,05)$, artinya pengalaman kerja berpengaruh positif dan signifikan terhadap produktivitas karyawan, yang berarti hipotesis 3 terbukti. 
Pada hipotesis 4 nilai t hitung untuk variabel Usia Karyawan adalah 1.757, sedangkan nilai t tabelnya sebesar $1.750(\mathrm{df}=50-4-1=45)$. Selain itu, nilai signifikansinya didapat 0,047 .sehingga didapat bahwa variabel usia karyawan berpengaruh terhadap produktivitas karyawan. Hal ini disebabkan nilai $\mathrm{T}$ hitung lebih besar daripada $t$ tabel. Niali t hitung $>\mathrm{t}$ table $(1.757>1,750)$ dan nilai signifikansi $(\alpha) 0,05(0,047<0,05)$, artinya usia karyawan berpengaruh positif dan signifikan terhadap produktivitas karyawan (hipotesis 4 terbukti).

Selanjutnya dihitung pula koefisien determinasi yang digunakan untuk mengetahui proporsi pengaruh variabel independen terhadap variabel dependen. Nilai $R^{2}$ menunjukan seberapa besar model regresi mampu menjelaskan variabilitas variabel terhadap variabel dependen. atau menunjukan proporsi pengaruh variabel independen terhadap variabel dependen. Adapun hasil perhitungan dapat dilihat pada tabel 3 sebagai berikut:

Tabel 3 Perhitungan Koefisien Determinasi

\begin{tabular}{|c|c|c|c|c|c|}
\hline Model & $\mathrm{R}$ & $\mathrm{R}$ square & $\begin{array}{c}\text { Adjusted } \\
\mathrm{R} \text { square }\end{array}$ & $\begin{array}{c}\text { Std. Error of the } \\
\text { Estimate }\end{array}$ & $\begin{array}{c}\text { Durbin- } \\
\text { Watson }\end{array}$ \\
\hline 1 & 0.671 & 0.638 & 0.761 & 0.23858 & 1.809 \\
\hline
\end{tabular}

a. Predictors: (Constant), usia, pengalaman kerja, motivasi kerja, tingkat pendidikan

b. Dependen Variabel: Produktivitas karyawan

Sumber: Data olah SPSS 16.00

Koefisien determinasi (Adjusted R square) yang diperoleh adalah sebesar 76.1\% tersebut merupakan nilai persentase pengaruh variabel independen tingkat pendidikan, Usia kerja, motivasi kerja dan pengalaman kerja terhadap produktivitas karyawan. Sedangkan sisanya sebesar $23.9 \%$ dijelaskan oleh variabel lain yang tidak diteliti.

\section{HASIL PENELITIAN DAN PEMBAHASAN}

Dari analisis hasil penelitian data diatas maka dapat dijelaskan bahwa: berdasarkan hasil penelitian dapat diketahui nilai uji t, untuk variabel tingkat pendidikan adalah 0.985, sedangkan nilai t tabelnya sebesar 1.750 (df $=50-4-1=$ 45). Selain itu, nilai signifikansinya didapat 0,375 . Sehingga dapat disimpulkan bahwa secara parsial tingkat pendidikan tidak berpengaruh terhadap produktivitas karyawan. Hal ini sejalan dengan hasil penelitian yang dilakukan oleh Subarjo 
(2015) bahwa tingkat pendidikan tidak berpengaruh secara parsial terhadap produktivitas karyawan. Tingkat pendidikan tidak berpengaruh diduga karena karyawan perusahaan menilai bahwa tingkat pendidikan dianggap belum tentu menjamin meningkatnya produktivitas karyawan.

Pada variabel motivasi kerja, nilai t hitung untuk variabel motivasi kerja adalah 1.851, sedangkan nilai t tabelnya adalah sebesar $1.750(\mathrm{df}=50-4-1=45)$. Selain itu nilai signifikansinya didapat 0,043 . Sehingga dapat disimpulkan bahwa secara parsial motivasi kerja berpengaruh terhadap produktivitas karyawan. Hal ini didukung dengan penelitian terdahulu yang dilakukan oleh Subarjo (2015) kemudian Arif Yusuf Hamali (2014) dan Desi Rahmawati (2013) bahwa motivasi kerja berpengaruh terhadap produktivitas karyawan. Dengan demikian motivasi kerja sangat penting dalam peningkatan produktivitas karyawan karena dengan motivasi yang tinggi akan mampu meningkatkan produktivitas tenaga kerja itu sendiri.

Pada Variabel Pengalaman Kerja, nilai t hitung untuk variabel Pengalaman kerja adalah 2.062, sedangkan nilai t tabelnya adalah sebesar 1.750 (df $=50$ - 4 $1=45)$. Selain itu nilai signifikansinya di dapat 0,040. Sehingga dapat disimpulkan bahwa secara parsial pengalaman kerja berpengaruh terhadap produktivitas karyawan. Hal ini di dukung dengan penelitian tedahulu yang dilakukan oleh Subarjo (2015) dan Yanti Itafia (2014) bahwa pengalaman kerja berpengaruh terhadap produktivitas karyawan. Dengan demikian pentingnya pengalaman kerja berpengaruh dalam peningkatan produktivitas setiap karyawan, karena semakin banyak pengalaman tentunya akan dapat meningkatkan kegiatan produktivitas.

Pada Variabel Usia Karyawan, nilai t hitung untuk variabel Usia Karyawan adalah 1,757, sedangkan nilai t tabelnya adalah sebesar 1,750 (df $=50$ 4-1 = 45). Selain itu, nilai signifikansinya didapat 0,047. Sehingga dapat disimpulkan bahwa secara parsial usia karyawan berpengaruh terhadap produktivitas karyawan. Hal ini di dukung dengan penelitian terdahulu yang dilakukan oleh Subarjo (2015) bahwa usia karyawan berpengaruh terhadap produktivitas karyawan. Jaminan ukuran usia sangat menentukan jumlah hasil produksinya, tentunya dengan asumsi apabila usianya tidak muda lagi 
produktivitas akan lebih lambat atau kecil daripada usia yang masih dibawahnya. Pentingnya dalam manajemen bagian sumber daya manusia dalam melakukan pembatasan usia kerja dari perusahaan tersebut.

\section{KESIMPULAN DAN SARAN}

\section{Kesimpulan}

Dari hasil penelitian dan pembahasan pada uraian sebelumnya, dapat di tarik simpulan sebagai berikut : pertama, secara parsial atau individu usia kerja, motivasi kerja dan pengalaman kerja berpengaruh positif dan signifkan terhadap produktivitas karyawan, sedangkan tingkat pendidikan tidak bepengaruh terhadap produktivitas karyawan pada CV Mitra Bersama Lestari secara signifikan. Kedua, secara bersama-sama tingkat pendidikan, usia kerja, motivasi kerja dan pengalaman kerja berpengaruh terhadap produktivitas karyawan dan ketiga, tingkat pengaruh indikator faktor-faktor yang mempengaruhi produktivitas karyawan diperoleh $76.1 \%$ menjelaskan bahwa naik turunya produktivitas karyawan secara bersama-sama mepengaruhi tingkat pendidikan, usia kerja, motivasi kerja, dan pengalaman kerja $23.9 \%$ dipengaruhi oleh variabel lain yang tidak diteliti.

\section{Saran}

Adapun saran yang bisa disampaikan atas hasil penelitian ini adalah : pertama, faktor yang perlu dipertimbangkan untuk ke depan terutama oleh pihak perusahaan adalah tentang subtansi dari motivasi kerja, usia kerja maupun pengalaman kerja. Dengan demikian diharapkan perusahaan nantinya akan menjadikan karyawan atau tenaga kerja yang handal dan mampu memproduksi secara optimal. Kedua, untuk bisa memproduksi atau menghasilkan barang yang maksimal dan optimal, maka perusahaan harus mencapai produktivitas perusahaan yang tinggi melalui penyeleksian tenaga kerja yang handal di samping meningkatkan kemampuan tenaga kerja dengan berbagai pelatihan diharapkan mampu mempunyai pengalaman. Dan yang ketiga, untuk selanjutnya diharapkan dapat mengembangkan penelitian ini dengan menilai variabel penelitian lainya 
yang dapat digunakan untuk menilai peningkatan produktivitas karyawan selain variabel dari penelitian diatas.

\section{DAFTAR PUSTAKA}

Anoraga, Pandji, 2005, Manajemen Bisnis, Cetakan Ketiga, Jakata:Rineka Cipta

Depdiknas, (2013). Kamus Besar Bahasa Indonesia, Edisi Ketiga, Jakarta : Balai Pustaka.

Elaine B. Johnson. 2007. Contextual Teaching and Learning. MLC Bandung.

Gomes, F. C. 2005. Manajemen Sumberdaya Manusia. Andi Offset. Yogyakarta. Organisasi dan Motivasi. Bina Pustaka. Jakarta.

Hamali AY, 2014. Pengaruh Motivasi terhadap Produktivitas Kerja ; Studi Kasus pada PT.X Bandung. Journal Volume 14, No.2 http://researchdashboard.binus.ac.id/uploads/paper/document/publication/Journal/The\% 20Winners/Vol.\%2014\%20No.\%202\%20September\%202013/02_Vol14-2\%20Arif\%20Yusuf\%20Hamali.pdf 18 mei 2016

Handoko, T. Hani. 2003. Manajemen, Cetakan Kedelapanbelas, BPFE Yogyakarta, Yogyakarta.

Handoyo, Rossanto Dwi, 2006 Materi Pokok Ekonomi Sumber Daya Manusia, Cetakan 1, Jakarta: Universitas Terbuka.

Hadari Nawawi. 2001. Manajemen Sumer Daya Manusia. Bumi Aksara. Jakarta.

Husein Umar. 2003. Riset SDM Dalam Organisasi. Edisi Revisi. Cetakan kelima. PT. Gramedia Pustaka Utama. Jakarta.

Imam, Ghozali. 2009. Aplikasi Multivariate dengan Program SPSS, Semarang: Badan Penerbit Universitas Diponegoro.

Itafia Yanti, dkk 2014. Pengaruh Pengalaman Kerja dan Kepuasan Kerja terhadap Produktivitas Kerja Karyawan pada Industri Tenun. Volume 2. http://download.portalgaruda.org/article.php?article=304551\&val=1350 $\&$ title $=$ PENGARUH\%20PENGALAMAN\%20KERJA\%20DAN\%20KE PUASAN\%20KERJA\%20TERHADAP\%20PRODUKTIVITAS\%20KE RJA\%20KARYAWAN\%20PADA\%20INDUSTRI\%20TENUN 18 Mei 2016

J. Simanjuntak, Payaman,dalam pajar 2007 Pengantar Ekonomi Sumber Daya Manusia, Lembaga Penerbit Fakultas Ekonomi Universitas Indonesia, Jakarta.

Kusnendi dkk. 2003 Ekonomi Sumber Daya Manusia dan Alam. Jakarta: Universitas Terbuka.

Ngalim Purwanto 2007 Psikologi Pendidikan, Jakarta: PT Remaja Rosdakarya.

Malayu S.P, Hasibuan. 2006, Manajemen Sumber Daya Manusia. Bumi Aksar. Jakarta. 
Marihot T. E Hariandja. 2005. Manajemen Sumber Daya Manusia.PT. Gramedia Widiasarana Indonesia. Jakarta.

Muchdarsyah (2003) Produktivitas apa dan bagaimana Jakarta; Bumi Aksara

Priyanto, Didik, (2006). “Analisis Tingkat Pendidikan dan Pengalaman Kerja Terhdap Produktivitas Kerja Karyawan Bagian Keperawatan pada

Rahmawati Desi, 2013. Pengaruh Motivasi terhadap Produktivitas Kerja Karyawan PR Fajar Berlian Tulungagung, Jurnal Bonorowo Volume 1 No.1. www.jurnal-unita.org/index.php/bonorowo/article/view/6/6 18 Mei 2016.

Saiful Rohmat 2007, Pengaruh Produktivitas Tenaga Kerja Terhadap Kinerja Perusahaan: Jurnal Ekonomi.

Sondang P Siagian. 2006. Manajemen Sumber Daya Manusia. PT. Bumi Aksara. Jakarta.

Subarjo, 2015. Faktor-faktor yang mempengaruhi produktivitas karyawan pada CV. Granada, Jurnal Ekonomi dan Bisnis OptimuM, Vol. 5 No.2, 2015 ISSN 1411-6022

Susilo Martoyo, 2004: Manajemen Sumber Daya Manusia, alfabeta: Bandung.

Van Den Ban. A.W. dan H.S Hawkins., 1999. Penyuluhan Pertanian. Kanisius. Yogyakarta.

Winardi, 2000, Manajer dan Manajemen. Bandung: Citra Aditya Bakti.

Yuniarsih, Tjujtu dan Suwanto. 2009; Manajemen Sumber Daya Manusia, Alfabeta. Bandung. 